\title{
Designing Student Attendance Information Systems Web-Base
}

\author{
Zaleha Fauziah ${ }^{1}$, Haznah Latifah², Untung Rahardja ${ }^{3}$, Ninda Lutfiani ${ }^{4}$, Aditya \\ Mardiansyah $^{5}$ \\ Manipal International University, Malaysia ${ }^{1,2}$, University of Raharja, Indonesia ${ }^{3,4,5}$ \\ e-mail: zalehafauziah@yahoo.com¹ ${ }^{1}$, haznahlatifah@yahoo.com², untung@raharja.info ${ }^{3}$, \\ ninda@raharja.info ${ }^{4}, \underline{\text { aditya.mardiansyah@raharja.info }}{ }^{5}$
}

To cite this document (APA Style):

Fauziah, Z., Latifah, H., Raharja, U., Lutfiani, N., \& Mardiansyah, A. (2021). Designing Student Attendance Information Systems Web-Based. Aptisi Transactions on Technopreneurship (ATT), 3(1), 23-31.

DOI: https://doi.org/10.34306/att.v3i1.114
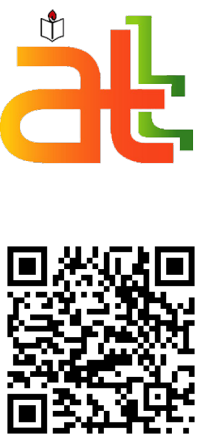

Author Notification 20 January 2021 Final Revised Published

31 March 2021

\begin{abstract}
Curug SMPN 1 is one of the state senior high schools in Tangerang regency, precisely in Curug district. The teacher absentee system in implementing learning has been running and is considered ineffective because it still has to record in books which are considered inefficient. To facilitate the need for teachers to record reports in books and to make it easier for supervisors, a web-based information system design was created. The method used is a prototype model using the help of an application from Adobe. With the prototype it is expected that the use of the WhatsApp service can be used to provide information to parents. The use of this prototype method is expected to be developed in other schools.
\end{abstract}

Keywords: Web, Desain, Application, WhatsApp Gateway, Student Attendance

\section{Introduction}

In the industrial era 4.0 where technology developed quite rapidly starting from the use of robots in the industrial world to the use of online learning or can be called E-Learning [1]. Computer technology is developing quite rapidly because the needs in the market are significant enough to help human work in any field. Even at school you are familiar with computers, to make it easier for a teacher to make absences a web-based application design is used to monitor a student for a student's guardian [2]. Theorists in education integrate various ways of integrating technology both physically and not into learning methods, so that it is known by the general term Education 4.0 or Education 4.0 [3] [4]. Successful education will creating decent and valuable people in the community so that it becomes important education to produce qualified and competitive human beings [5].

in the current era, educational institutions both the lowest level, namely from elementary school to high school level are required to compete globally [6]. With real action technological sophistication can now be accessed anywhere and anytime [7]. The manifestation of teacher professionalism is that the teacher must be able to master the teaching skills where one of the important skills that must be mastered by the teacher is to succeed in the skills to explain the lessons that are part of the method [8] [9].

The purpose of this application is: design and build a student attendance reporting application using WhatsApp gateway for parents' supervision [10]. In the design of achievement HR system development, found an obstacle, among others, HR performance data is only managed by the leader so that achievement recommendations are not carried out transparently 
and management that is not carried out effectively and efficiently does not indicate the quality of data in the field in an update [11] [12]. Because the needs of a system, then made a system that can replace the old system to be more effective and efficient [13][14].The information system that will be built will help students and parents access their information through the internet and get information without the need to go to school, simply by accessing the internet to the school's website and finding school information needed [15][16] [17].

In the old system there are deficiencies that allow the system to be changed for the better. So that it can be expected to be implemented in a product that will correct any deficiencies that exist in the old system [18].

\section{Research Method}

The problem that occurs at this time is the lack of management in the knowledge and skills of technology in the education sector so that this can easily reduce human resources who do not have the skills and technology to support education will have no interest in the era of disruption [19].

\subsection{Literature Review}

Attendance system which is a system which is used to record attendance records every member of the agency [20]. The author conducts library research to obtain theoretical aspects in collecting data and information through reference books, scientific journals and other material related to the issues reviewed in the preparation of this research [21].

This research is to identify attendance problems and avoid attendance errors which are done manually. So, there are five studies that have a unidirectional correlation with this research:

1. In a research journal conducted by Noval Aditya Muhammad, febriliyan Samopa and Radityo Prasetianto Wibowo with the title "Making Fingerprint-Based Lecture Attendance Applications" in 2013. The research discusses how a fingerprint-based attendance system is used to support the learning process, besides preventing fraudulent attendance done in class. This technology is on the rise and very supportive because its application is not difficult and affordable. But JSI hasn't maximized the application of fingerprint presence because it doesn't have an application that manages that presence yet.

2. In a research journal conducted by Wahyu Adam, M.Eng. Sc and Lamhot Sagala with the title "Employee Attendance System Using RFID Technology" in 2013. The following research aims to design a prototype of an RFID attendance system integrated with a database to support an attitude improvement program. discipline towards employees is a form of the first step in improving the company's overall performance. The RFID prototype attendance system consists of several components, namely the tag that will be used as a substitute for the ID card and the reader which is used to read information regarding the attendance of employees, database integration in this system allows the two to be stored automatically into the database.

3. In a journal research conducted by Eko Budi Setiawan and Bobi Kurniawan with the title "Lecture Attendance System Design Using Radio Frequency Identification (RFID)" in 2015. This study aims to minimize errors in the lecture environment related to attendance problems so that a system using RFID because it is quite effective and efficient.

4. In a journal research conducted by Taufik Ramadhan and Victor G Utomo with the title "Designing Mobile Applications for Android-Based Lecture Schedule Notifications" in 2014. The research aimed at updating an earlier system with a mobile application running on android because in terms of using android easier and more effective.

5. In the thesis research conducted by Hartanto with the title Employee Attendance Information System Design with Barcode Scanner Card at PT. Skyputra Pancasurya" in 2013. This study aims to improve the attendance system for employees because the system is still manual using an attendance paper form which will be deposited to HRD to be recorded. Therefore, researchers suggest using a barcode scanner in the attendance system because it is more effective and efficient.

\subsection{Research Methodology}


Prototype is defined as a version of a potential system that gives ideas to developers and potential users, how the system will function in its completed form [22]. The system development method used in this research is the prototype method in which the prototype model collects certain information about the user's information needs quickly [23]. The prototype method consists of the following:

a. Gathering needs

Stakeholders and designers will jointly determine the overall format of the two software, identify all appropriate requirements, and outline the system that will be created by the designer.

\section{b. Build a Prototype}

Build a prototyping by making designs that are temporary and focused by presenting to stakeholders.

\section{c. Prototype Evaluation}

Evaluation carried out by stakeholders, whether the prototype is built in accordance with the wishes of stakeholders or not. If it fits the concept, continue to the next stage. But if not, the prototype will be revised by repeating the steps from before.

d. Encode the system

At this stage the prototype that has been agreed upon will be translated into a programming language according to the wishes of the design that has been proposed based on the wishes of the stakeholders.

\section{e. Test the System}

if the system has finished being a software that is ready to be used, then the next step is to process the system testing.

\section{f. System Evaluation}

Stakeholders evaluate whether the ready-made software is as expected. If yes, the process will continue to the next stage, but if the finished software does not match what is expected, the previous steps will be repeated.

g. Use the System

A software that has passed the system testing stage and is accepted and ready to use the system by stakeholders. 


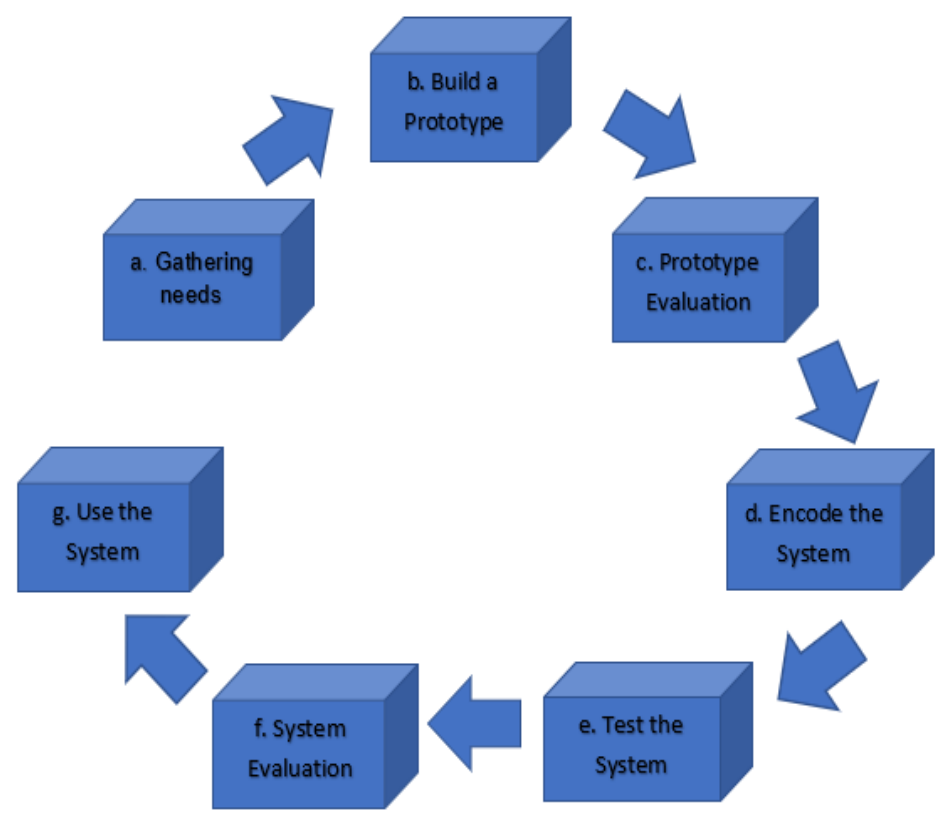

Picture 1. Prototype Model

\section{Findings}

The results of developing a software product maintenance management application are described in the form of Unified Modeling Language (UML) and User Interface (UI) design [24].

\subsection{Usecase Diagram}

Use case is a pattern or a picture show system behavior or habits [25]. UML provides a lot of diagrams needed to explain the system being developed, both from the static and dynamic aspects [26]. Each use case consists of one or more scenarios that explain how the system interacts with users or other systems to achieve a certain business goal [27]. To make a design that is optimal enough, a use case is needed to help design it to match what is expected. The following is an explanation of the use case diagram of the system to be designed:

1. The user logs in first

2. Users will enter the main page

3. The user enters the data of the teaching class, the lesson code (the subject will appear according to the code chosen), the last is to choose a date / month / year then submit.

4. The user is absent.

5. After the lesson, the user can log out so that the data is not misused. After that the admin will process to send absent information to the student guardians. 


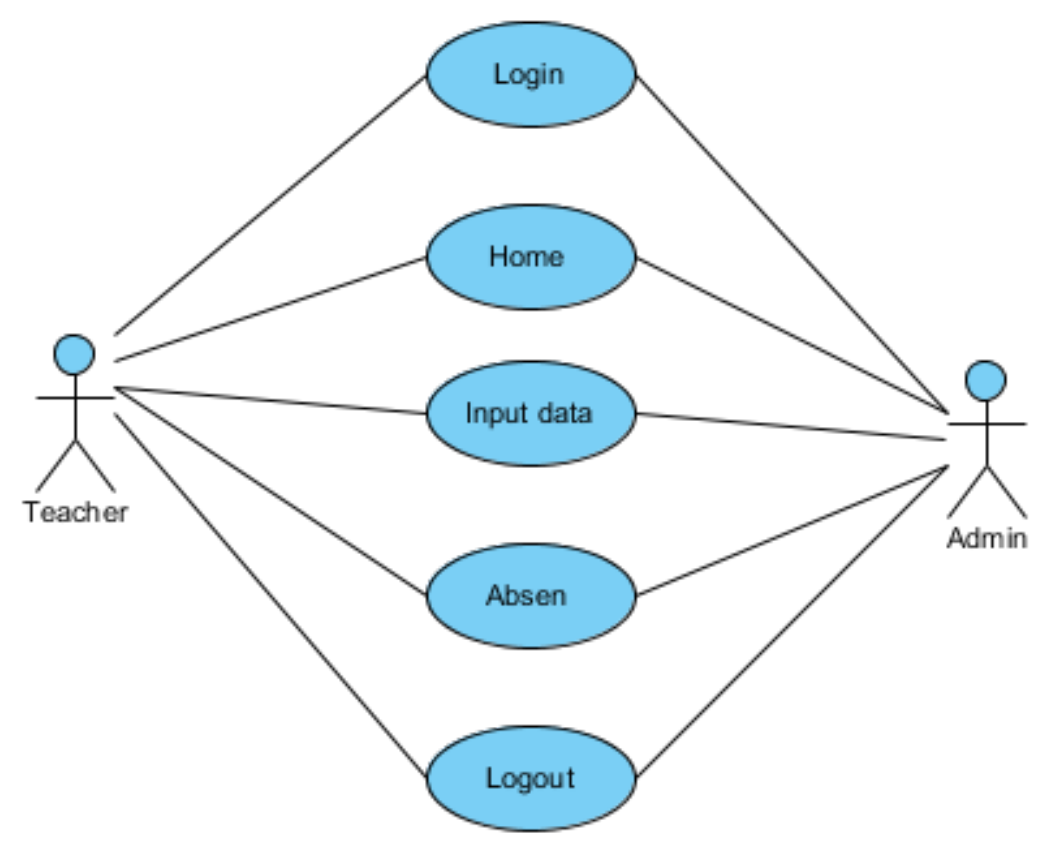

Picture 2. Usecase Diagram

\subsection{Activity Diagram}

Activity Diagram is a design of activity flow or work flow in a system that will be run. In full, the activity diagram defines where the workflow starts, where it stops, what activities occur during the workflow, and how the sequence of events occur [28].

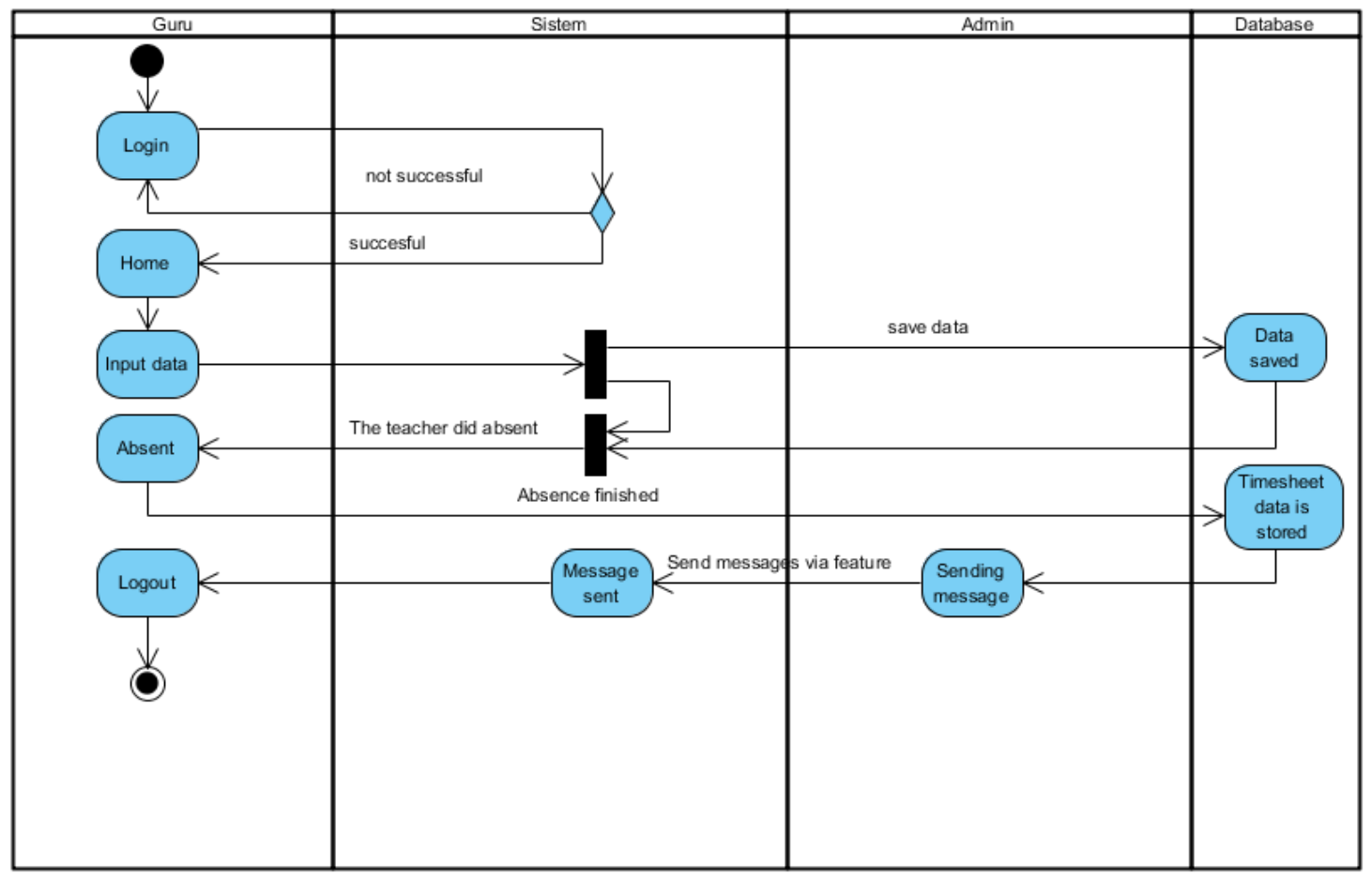

Picture 3. Activity Diagram 


\subsection{UI Design}

In designing a website there are things that must be considered such as beauty, functional and others [29]. The main purpose of the website must be to allow users to get information from the site quickly, so that the user interface is something that needs to be considered [30][31].

In the display web page preceded by login, the login form there is a username and password. At login, the system will process whether or not the username and password are entered. if it matches, it will switch to the dashboard.

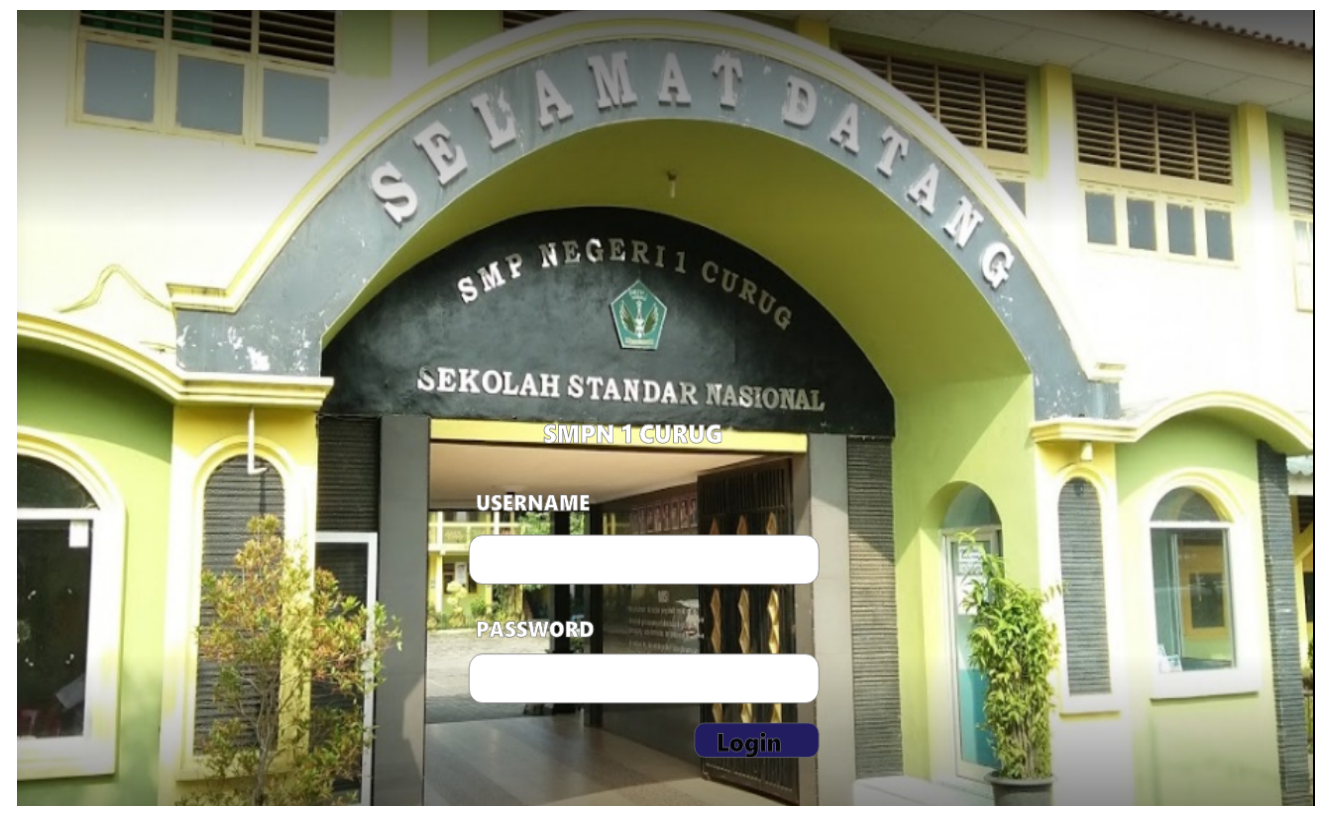

Picture 4. Form Login

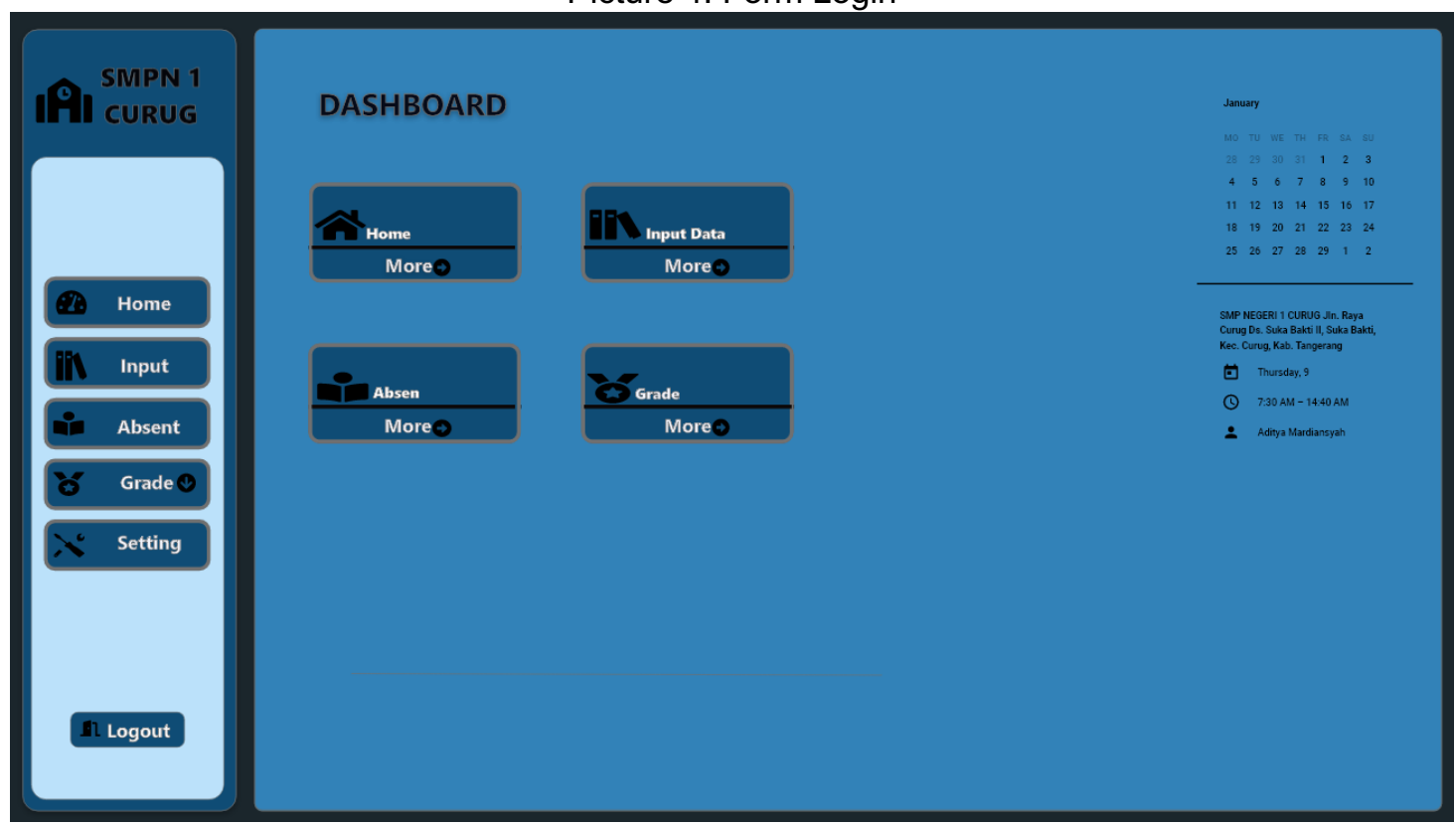

Picture 5. Dashboard 


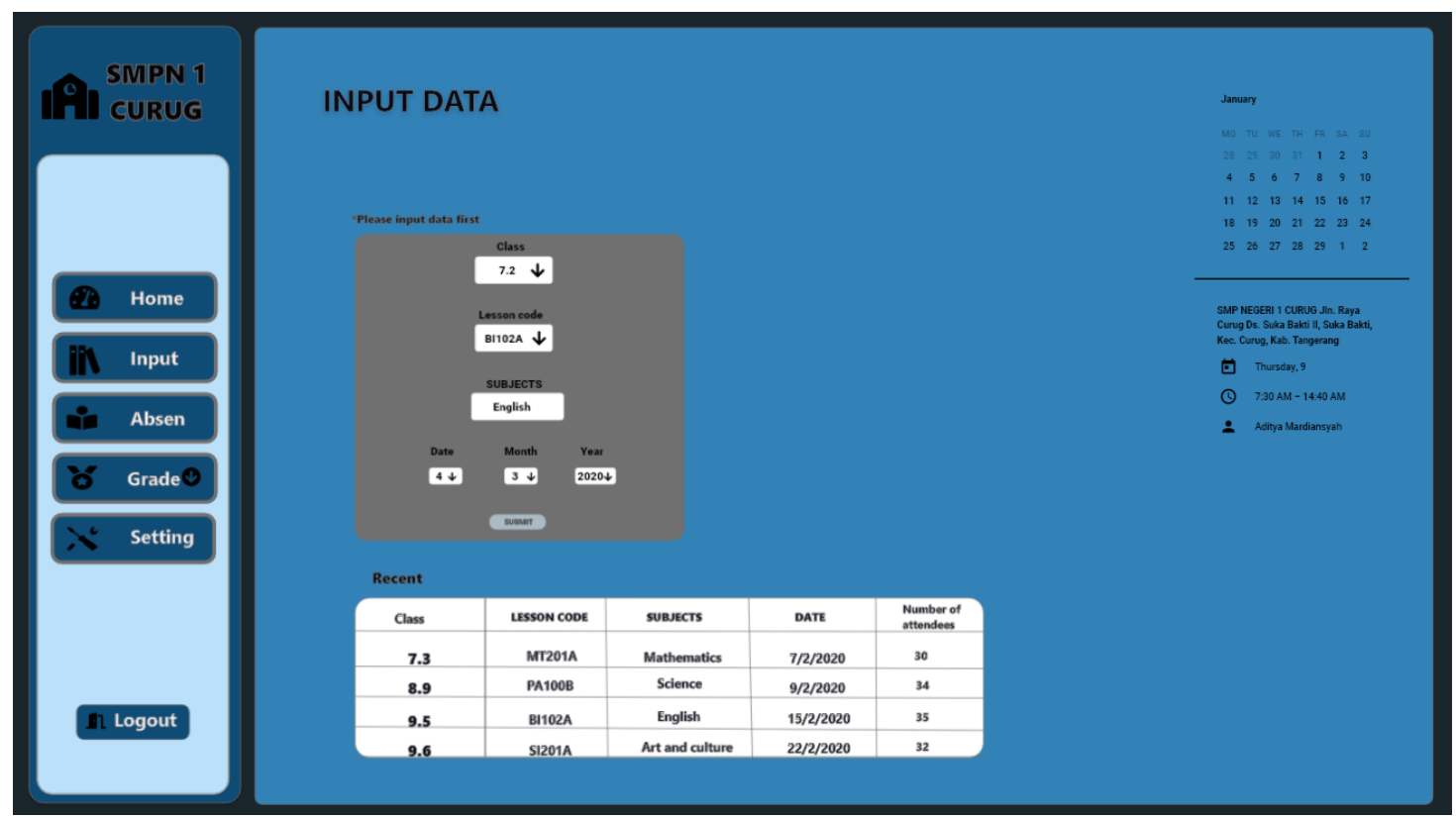

Picture 6. Data input form

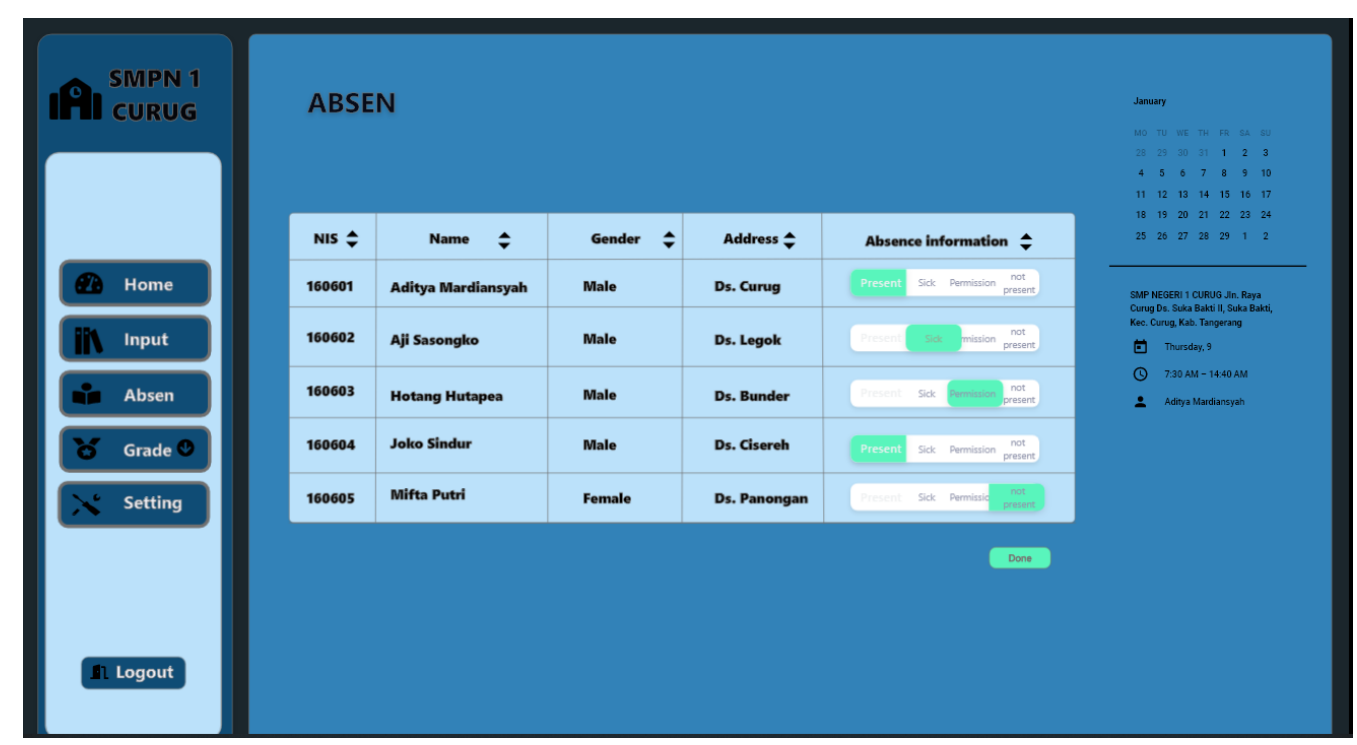

Picture 7. Absent students

After the absence is complete, the admin will send a message to the student's guardian to provide information on whether the student entered the school or not through the WhatsApp application with the WhatsApp gateway system. WhatsApp Gateway is one of the many APIs that have the ability to send messages to other platforms [32]. 


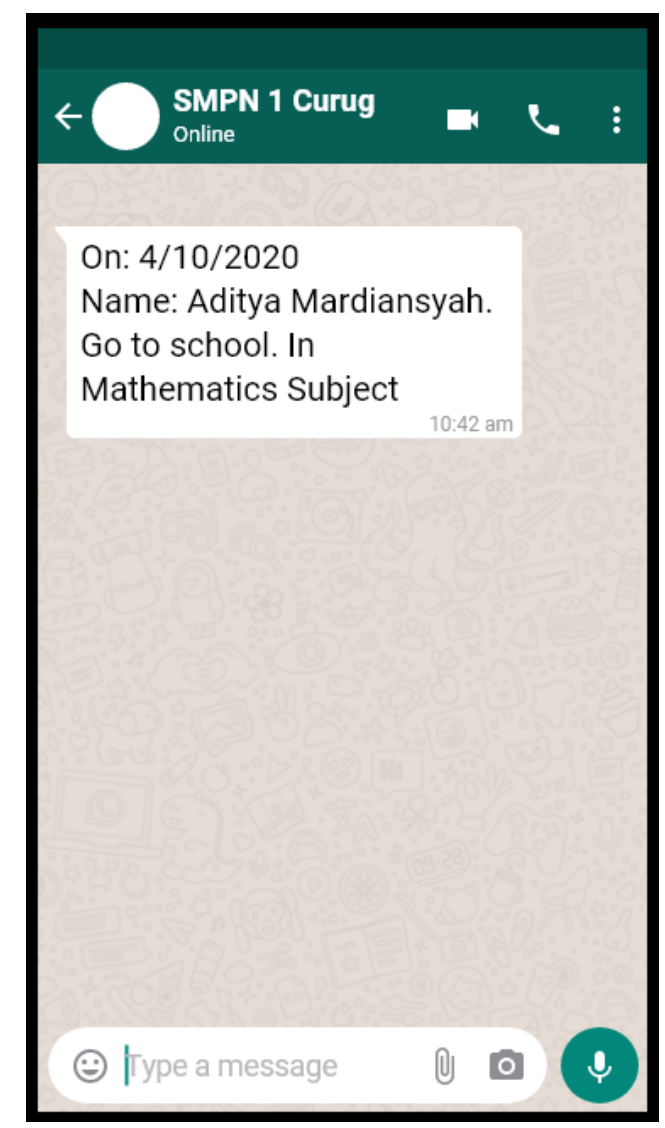

\section{Conclusion}

Picture 8. Notifications via WhatsApp

So, it can be concluded that this design can be an illustration for the system to be created and the design of this system can be developed into a student information system that can be used to input student scores online at SMPN 1 Curug. The advantage is that it helps teachers enter grades when the system design is created and makes it easier for administrators to manage student grades. The weakness of this design is that it is still a design that has not been implemented and is still not a mobile application. The proposed design can also be applied to other schools so that parents can monitor their children's activities remotely. Sorry if in writing there are still many shortcomings, more or less apologize and thank you.

\section{References}

[1] W. Winarno, Y. Muhtadi, and M. A. Aldiya, "Application of Learning Management Using Non-test Instrument to Improve the Quality of Education," Aptisi Trans. Manag., vol. 3, no. 1, pp. 46-56, 2019.

[2] A. S. Bein, Y. I. Graha, and A. P. Pangestu, "Pandawan Website Design Based Content Management System As Media E-commerce Transaction," Aptisi Trans. Technopreneursh., vol. 2, no. 1, pp. 87-97, 2020.

[3] U. Rahardja, N. Lutfiani, E. P. Harahap, and L. Wijayanti, "iLearning: Metode Pembelajaran Inovatif di Era Education 4.0," Technomedia J., vol. 4, no. 2, pp. 261-276, 2020.

[4] Q. Aini, I. Dhaniarti, and A. Khoirunisa, "Effects of iLearning Media on Student Learning Motivation," Aptisi Trans. Manag., vol. 3, no. 1, pp. 1-12, 2019.

[5] U. Raharja, N. Lutfiani, I. Handayani, and F. M. Suryaman, "Motivasi Belajar Mahasiswa Terhadap Metode Pembelajaran Online iLearning+ Pada Perguruan Tinggi," SISFOTENIKA, vol. 9, no. 2, pp. 192-202, 2019.

[6] J. Hom, B. Anong, K. B. Rii, L. K. Choi, and K. Zelina, "The Octave Allegro Method in 
Risk Management Assessment of Educational Institutions," Aptisi Trans. Technopreneursh., vol. 2, no. 2, pp. 167-179, 2020.

[7] Q. Aini, U. Rahardja, A. H. Arribathi, and N. P. L. Santoso, "Penerapan Cloud Accounting dalam Menunjang Efektivitas Laporan Neraca pada Perguruan Tinggi," Comput. Eng. Sci. Syst. J., vol. 4, no. 1, pp. 60-64, 2019.

[8] A. A. Utomo, A. Imron, and M. Syaiful, "Pengaruh Penjelasan Guru terhadap Pemahaman Siswa pada Mata Pelajaran Sejarah," PESAGI (Jurnal Pendidik. dan Penelit. Sejarah), vol. 5, no. 8, 2017.

[9] U. Rahardja, Q. Aini, and A. Khoirunisa, "The Effect of Rinfogroups as a Discussion Media in Student Learning Motivation," Aptisi Trans. Manag., vol. 2, no. 1, pp. 79-88, 2018.

[10] D. Martin, "PENGEMBANGAN SISTEM PELAPORAN PRESENSI SISWA MENGGUNAKAN WHATSAPP GATEWAY DENGAN METODE BROADCAST BERBASIS ANDROID." Universitas Pendidikan Indonesia, 2019.

[11] D. P. Sari, O. M. Febriani, and A. S. Putra, "Perancangan Sistem Informasi SDM Berprestasi pada SD Global Surya," in Prosiding Seminar Nasional Darmajaya, 2018, vol. 1, no. 1, pp. 289-294.

[12] F. Sudarto and A. Yondari, "Web-Based Population Cencus Design In Neighborhood Building," Aptisi Trans. Technopreneursh., vol. 2, no. 1, pp. 18-24, 2020.

[13] S. Rahayu, Y. Muhtadi, and A. Al Farobie, "Design Of Web Based Employees Information System Design in SD Kumnamu School Tangerang," Aptisi Trans. Manag., vol. 1, no. 2, pp. 130-135, 2017.

[14] U. Rahardja, I. Handayani, N. Lutfiani, and F. P. Oganda, "An Interactive Content Media on Information System iLearning+," IJCCS (Indonesian J. Comput. Cybern. Syst., vol. 14, no. 1, pp. 57-68, 2020.

[15] M. Susanti, "Perancangan Sistem Informasi Akademik Berbasis Web Pada Smk Pasar Minggu Jakarta," J. Inform., vol. 3, no. 1, 2016.

[16] A. Alwiyah, C. Greisy, and A. Afitri, "Implementation Of Information Systems On Ecommerce Websites As Media To Deliver Information," Aptisi Trans. Technopreneursh., vol. 1, no. 2, pp. 127-133, 2019.

[17] S. Santoso, J. Kauf, and N. C. Aristo, "The Information System of Name Card Sales Based on Digital Marketing to Improve Creativepreneur on College E-Commerce Website," Aptisi Trans. Technopreneursh., vol. 1, no. 1, pp. 64-72, 2019.

[18] C. F. A. Sari and L. Yulianto, "Perancangan sistem informasi absensi menggunakan finger print di badan perencanaan pembangunan daerah dan penanaman modal kabupaten pacitan," in Seruni-Seminar Riset Unggulan Nasional Inoformatika dan Komputer, 2013, vol. 2, no. 1.

[19] F. Agustin, F. P. Oganda, N. Lutfiani, and E. P. Harahap, "Manajemen Pembelajaran Daring Menggunakan Education Smart Courses," Technomedia J., vol. 5, no. 1, pp. 4053, 2020.

[20] A. S. Rintjap, S. R. U. A. Sompie, and O. Lantang, "Aplikasi absensi siswa menggunakan sidik jari di Sekolah Menengah Atas Negeri 9 Manado," J. Tek. Elektro Dan Komput., vol. 3, no. 3, pp. 1-5, 2014.

[21] M. A. AS and N. A. Septiani, "Perancangan Sistem Informasi Akademik Menggunakan Metode Waterfall Studi Kasus: Madrasahaliyah Al-Mansyuriyah Kanza Mekarjaya Tangerang," J. Techno Nusa Mandiri, vol. 13, no. 2, pp. 165-172, 2016.

[22] A. S. Rafika, I. Faridah, and A. A. Sangaji, "KKN Management Center and Region Development Research Institutions and Community Devotion State University of Yogyakarta," Aptisi Trans. Manag., vol. 1, no. 1, pp. 61-69, 2017.

[23] S. A. Lahallo and R. D. Aritonang, "Design of a Copy Service E-Marketplace AndroidBased in the Parongpong District," Aptisi Trans. Technopreneursh., vol. 2, no. 1, 2020, doi: 10.34306/att.v2i1.65.

[24] H. Noprisson and B. Budiyarti, "Aplikasi Manajemen Pemeliharan Produk Perangkat Lunak," J. Sci. Appl. Informatics, vol. 1, no. 2, pp. 41-45, 2018.

[25] Y. Simaremare, A. Pribadi, and R. P. Wibowo, "Perancangan dan Pembuatan Aplikasi Manajemen Publikasi IImiah Berbasis Online pada Jurnal SISFO," J. Tek. ITS, vol. 2, no. 
3, pp. A470-A475, 2013.

[26] T. A. Kurniawan, "Pemodelan Use Case (UML): Evaluasi Terhadap beberapa Kesalahan dalam Praktik," J. Teknol. Inf. dan IImu Komput, vol. 5, no. 1, p. 77, 2018.

[27] N. Artina, "Penerapan Analisis Kebutuhan Metode Use Case pada Metode Pengembangan Terstruktur," @ Igoritma, vol. 2, no. 3, pp. 1-6, 2006.

[28] E. Febriyanto and Q. Aini, "Multimedia-Based Visual Analysis As A Promotional Media At Raharja Internet Cafe (RIC)," Aptisi Trans. Manag., vol. 4, no. 1, pp. 76-82, 2020.

[29] I. Handayani, N. Lutfiani, and C. Y. Kristanti, "RANCANG BANGUN SISTEM PENGELOLAAN HAK KEKAYAAN INTELEKTUAL BERBASIS WEB PADA UNIVERSITAS RAHARJA," J. Pendidik. Teknol. dan Kejuru., vol. 17, no. 1, pp. 85-94, 2020.

[30] Henderi, Q. Aini, N. P. L. Santoso, A. Faturahman, and U. Rahardja, "A proposed gamification framework for smart attendance system using rule base," J. Adv. Res. Dyn. Control Syst., vol. 12, no. 2, pp. 1827-1838, 2020, doi: 10.5373/JARDCS/V12I2/S20201226.

[31] I. Handayani, E. Febriyanto, and A. Jethro, "Designing Popular Classes On Viewboard Public Assessment Of Lectures Based On Yii Framework," Aptisi Trans. Technopreneursh., vol. 1, no. 2, pp. 144-156, 2019.

[32] T. R. W. P. P. Indonesia, W. I. Rahayu, and N. Riza, "APLIKASI PEMESANAN BAHAN BAKAR MINYAK MELALUI MEDIA WHATSAPP MENGGUNAKAN ALGORITMA WHATSAPP GATEWAY (STUDI KASUS: PT. PERTAMINA PATRA NIAGA)." 